\title{
Thermal treatment effect on structural features of mechano-synthesized fluorapatite-titania nanocomposite: A comparative study
}

\author{
Bahman NASIRI-TABRIZI* \\ Materials Engineering Department, Najafabad Branch, Islamic Azad University, Najafabad, Isfahan, Iran
}

Received: November 10, 2013; Revised: November 24, 2013; Accepted: November 29, 2013

CThe Author(s) 2014. This article is published with open access at Springerlink.com

\begin{abstract}
The influence of thermal treatment on the structural features of mechano-synthesized fluorapatite-titania composite nanopowders was studied. A mixture of calcium and phosphate reagents was mixed with a certain amount of titania $(20 \mathrm{wt} \%)$ and then was mechanically activated for $5 \mathrm{~h}, 10 \mathrm{~h}$ and $15 \mathrm{~h}$ respectively. After that, the mechano-synthesized powders were annealed at $700{ }^{\circ} \mathrm{C}$ for $2 \mathrm{~h}$. The crystallite size of the composite nanopowders estimated from Williamson-Hall method was in good agreement with transmission electron microscopy (TEM) analysis. Scanning electron microscopy (SEM)/TEM images confirmed the formation of a cluster-like composite which was composed of ellipse-like nanoparticles with an average size of about $16 \pm 7 \mathrm{~nm}$ after $15 \mathrm{~h}$ of milling. During the milling process, large variations in mechanochemical behavior of the $\mathrm{CaHPO}_{4}-\mathrm{Ca}(\mathrm{OH})_{2}-\mathrm{CaF}_{2}-\mathrm{TiO}_{2}$ system were detected. After the beginning of milling, no trace of the composite was found due to the lack of sufficient time for the mechanical activation. When the mechanical activation time increased to $15 \mathrm{~h}$, composite nanopowders with the crystallite size of around $21.66 \mathrm{~nm}$ were formed. During heating at $700{ }^{\circ} \mathrm{C}$, the recovery of crystallinity occurred and the fraction of crystalline phase reached a maximum around $88.79 \%$ for the 10 -h milled sample. Results indicated that the structural features of the composite were strongly influenced by the subsequent annealing.
\end{abstract}

Keywords: nanocomposite; fluorapatite; thermal treatment; Williamson-Hall method; structural features

\section{Introduction}

One of the most important aspects of nanotechnology is the modification and design of solids to obtain functionalized materials with tailored properties [1]. In the field of biomaterials, hydroxyapatite (HAp,

* Corresponding author.

E-mail: bahman_nasiri@hotmail.com
$\left.\mathrm{Ca}_{10}\left(\mathrm{PO}_{4}\right)_{6}(\mathrm{OH})_{2}\right)$ is one of the most frequent forms of bioceramics in biological organisms which shows excellent biocompatibility with various kinds of cells and tissues [2]. The close chemical similarity of HAp to natural bone has led to the extensive research efforts to use synthetic HAp (s-HAp) as a bone substitute and/or replacement in biomedical applications [3]. Besides, HAp and its modified structures have been investigated for drug delivery [4], gene therapy [5], 
chromatography [6] and waste water remediation [7]. Over the past, nanostructured materials become very common in biomedical applications [8,9]. These structures can exhibit enhanced mechanical, biological, chemical, electrochemical or magnetic properties compared with their conventional counterparts [10]. However, HAp has intrinsically high dissolution rate in a biological system, poor corrosion resistance in an acidic environment and poor chemical stability at high temperature $[11,12]$.

One of the best methods to modify HAp is substitution of $\mathrm{OH}^{-}$groups by several anions like $\mathrm{OH}^{-}$, $\mathrm{F}^{-}, \mathrm{Cl}^{-}, \mathrm{Br}^{-}, \mathrm{O}^{2-}$ and $\mathrm{CO}_{4}^{2-}$ [2]. In the presence of $\mathrm{F}^{-}$ group, this modification leads to the formation of fluorine-substituted HAp (FHAp, $\mathrm{Ca}_{10}\left(\mathrm{PO}_{4}\right)_{6}(\mathrm{OH})_{2-x} \mathrm{~F}_{x}$, $0 \leqslant x \leqslant 1$ ) which causes an increase in crystallinity degree, a decrease in crystal strain and a rise in thermal stability [13]. From the perspective of biomedical knowledge, the incorporation of bioinert ceramics into calcium phosphates can improve their mechanical properties. Hence, numerous attempts have been made to develop new bioceramics with advanced mechanical and biological properties [14-16]. Among the reinforcing agents, titania $\left(\mathrm{TiO}_{2}\right)$, zirconia $\left(\mathrm{ZrO}_{2}\right)$ and alumina $\left(\mathrm{Al}_{2} \mathrm{O}_{3}\right)$ are more common materials due to their superb strength and fracture toughness [17-19]. However, specific precautions need to be taken to avoid adverse reactions between apatite and reinforcements during the fabrication process [20]. In general, severe plastic deformation (SPD) is one of the impressive methods to produce nanostructured materials. Examples of such methods include equal-channel-angular extrusion, torsion straining, accumulative roll-bonding, multiple forging, mechanical alloying (MA) and surface nanocrystallization [21]. During the MA process, powder particles are repeatedly flattened, cold welded, fractured and re-welded [22]. In fact, the MA process contains high internal stress that affects the nanostructural characteristics [23]. In such circumstances, X-ray diffraction (XRD) line broadening of these materials is due to both crystallite refinement and lattice micro-strains plus instrumental broadening. Accordingly, the grain sizes and lattice micro-strains of the mechanically alloyed powders have been estimated by XRD coupled with direct measurement of grain sizes using transmission electron microscopy (TEM) [24,25]. Although the grain size estimated from XRD can be corroborated by TEM, the determination of the lattice micro-strain often relies on XRD only [21]. The Scherrer formula can be used to evaluate the crystallite size directly if there is no lattice micro-strain. Besides, the Stokes-Wilson equation can be served to determine the lattice micro-strain if the crystallite size is adequately large [26]. However, in the presence of broadening from both fine crystallites and lattice micro-strains, Williamson-Hall method is often applied. This method is a simplified approach that clearly differentiates between size-induced and strain-induced peak broadenings by considering the peak width as a function of $2 \theta$ [22].

According to our recent findings [27], the crystallinity degree of mechano-synthesized fluorapatite-titania $\left(\mathrm{FAp}-\mathrm{TiO}_{2}\right)$ nanocomposite was effectively influenced by the milling time. In the present study, the influence of subsequent annealing on the structural features of mechano-synthesized FAp- $\mathrm{TiO}_{2}$ composite nanopowders was investigated. XRD line-broadening analysis has been used to estimate the grain size and lattice strain of the composite nanopowders. To corroborate the grain size measurement derived from the XRD data, detailed investigations were carried out by TEM and scanning electron microscopy (SEM). In addition, the crystallinity degree, volume fraction of grain boundary and lattice parameters were examined as a part of comparative study.

\section{Materials and methods}

\section{1 Preparation of composite nanopowders}

Figure 1 shows a schematic overview of solid-state process to produce $\mathrm{FAp}-\mathrm{TiO}_{2}$ composite nanopowders. In summary, analytical grade anhydrous dicalcium phosphate $\left(\mathrm{CaHPO}_{4}\right.$, Merck), calcium hydroxide $\left(\mathrm{Ca}(\mathrm{OH})_{2}\right.$, Fluka), calcium fluoride $\left(\mathrm{CaF}_{2}\right.$, Merck $)$ and titanium dioxide $\left(\mathrm{TiO}_{2}\right.$, Merck) were used as the raw materials. MA was performed at room temperature under air atmosphere using a high-energy planetary ball mill with polyamide- 6 vials $(125 \mathrm{ml}$ in volume) and zirconia balls (20 $\mathrm{mm}$ in diameter). In accordance with the stoichiometric $\mathrm{Ca} / \mathrm{P}$ content in the composition of FAp $(\mathrm{Ca} / \mathrm{P}=1.67)$, the mole ratio of calcium to phosphorus was 5 to 3 . In all the samples, the weight ratio of ball-to-powder (BPR), total powder mass and rotational speed were 20:1, $6 \mathrm{~g}$ and $600 \mathrm{rpm}$, respectively. To produce $\mathrm{FAp}-\mathrm{TiO}_{2}$ 


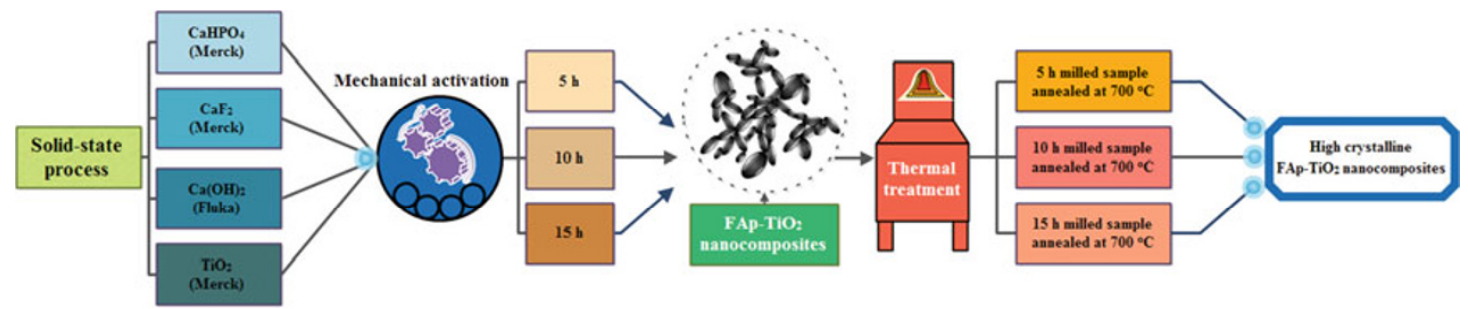

Fig. 1 A schematic overview of solid-state process to produce $\mathrm{FAp}-\mathrm{TiO}_{2}$ composite nanopowders.

composite nanopowders (reaction (1)), a mixture of $\mathrm{CaHPO}_{4}, \mathrm{Ca}(\mathrm{OH})_{2}$ and $\mathrm{CaF}_{2}$ was mixed with a certain amount of titania $(20 \mathrm{wt} \%)$ and then was mechanically activated for $5 \mathrm{~h}, 10 \mathrm{~h}$ and $15 \mathrm{~h}$ respectively without using any process control agent (PCA).

$$
\begin{gathered}
6 \mathrm{CaHPO}_{4}+3 \mathrm{Ca}(\mathrm{OH})_{2}+\mathrm{CaF}_{2}+\mathrm{TiO}_{2} \rightarrow \\
\mathrm{Ca}_{10}\left(\mathrm{PO}_{4}\right)_{6} \mathrm{~F}_{2}+\mathrm{TiO}_{2}+6 \mathrm{H}_{2} \mathrm{O}
\end{gathered}
$$

To evaluate the influence of thermal treatment on the structural evolution, all the milled specimens were filled in a quartz boat separately, and then were annealed under atmospheric pressure at $700{ }^{\circ} \mathrm{C}$ for $2 \mathrm{~h}$. In the thermal cycle, the heating rate from room temperature up to the desired temperature was fixed at $10{ }^{\circ} \mathrm{C} / \mathrm{min}$. Specifications of the synthesis process and abbreviated names of the specimens are given in Table 1.

Table 1 Specifications of the synthesis process and abbreviated names of the specimens

\begin{tabular}{lccc}
\hline \multirow{2}{*}{ Series } & \multicolumn{3}{c}{ Process condition } \\
\cline { 2 - 4 } & 1 & 2 & 3 \\
\hline Series 1 & MA $(5 \mathrm{~h})$ & $\mathrm{MA}(10 \mathrm{~h})$ & $\mathrm{MA}(15 \mathrm{~h})$ \\
Series 2 & $\mathrm{MA}(5 \mathrm{~h})+$ & $\mathrm{MA}(10 \mathrm{~h})+$ & $\mathrm{MA}(15 \mathrm{~h})+$ \\
& $\mathrm{TT}\left(700^{\circ} \mathrm{C}\right)$ & $\mathrm{TT}\left(700{ }^{\circ} \mathrm{C}\right)$ & $\mathrm{TT}\left(700{ }^{\circ} \mathrm{C}\right)$ \\
\hline
\end{tabular}

MA: Mechanical activation; TT: Thermal treatment.

\section{2 Characterization of composite nanopowders}

The phase compositions and structural evolutions of the composite nanopowders before and after annealing were investigated by XRD (Philips X-ray diffractometer, $\mathrm{Cu} \mathrm{Ka}$ radiation, $40 \mathrm{kV}, 30 \mathrm{~mA}$ and step scan of $\left.0.02\left({ }^{\circ}\right) / \mathrm{s}\right)$. The measurements were performed at room temperature with the diffraction range of $20^{\circ} \leqslant 2 \theta \leqslant$ $60^{\circ}$ at scan speed of $1\left(^{\circ}\right) / \mathrm{min}$. "PANalytical X'Pert HighScore" software was used to analyze the diffraction peaks. The XRD profiles were compared to standards compiled by the Joint Committee on Powder Diffraction and Standards (JCPDS), which involved cards \#15-0876 for FAp, \#009-0080 for $\mathrm{CaHPO}_{4}$, $\# 001-1274$ for $\mathrm{CaF}_{2}, \# 001-1079$ for $\mathrm{Ca}(\mathrm{OH})_{2}$ and \#01-071-1166 for $\mathrm{TiO}_{2}$. The functional groups were measured by Fourier transformed infrared (FT-IR) transmission spectroscopy (BRUKER, TENSOR27, Germany) in the range of $4000-400 \mathrm{~cm}^{-1}$. Energy dispersive X-ray spectroscopy (EDX) which was coupled to SEM was used for semi-quantitative examination of the composite. The agglomerate size distribution of the composite was examined by SEM (SERON AIS-2100). Besides, a more detailed morphological analysis was performed using TEM (Philips CM10, Eindhoven, the Netherlands) operated at the acceleration voltage of $100 \mathrm{kV}$.

\section{Results and discussion}

\section{1 SEM-EDX and TEM analysis}

The morphological features and the result of elemental analysis of the mechano-synthesized $\mathrm{FAp}-\mathrm{TiO}_{2}$ composite nanopowders are shown in Fig. 2. According to the SEM image (Fig. 2(a)), the large agglomerates with irregular shape are formed after $15 \mathrm{~h}$ of milling due to the coalescence of fine agglomerates/particles. It is clear that agglomerate is composed of very fine particles that are normally not visible in SEM micrograph. The homogeneity of composition was determined by measuring concentration ratios of calcium, phosphorus, oxygen, fluorine and titanium from various parts of $\mathrm{FAp}-\mathrm{TiO}_{2}$ composite (Fig. 2(b)). The EDX results indicate that a very homogeneous distribution of components was formed after $15 \mathrm{~h}$ of milling. In addition, no chemically stable contaminant is found due to the excessive adhesion of powders to the milling media. Figures 2(c) and 2(d) show the TEM images and a schematic view of the composite nanopowders, respectively. According to these figures, it is evident that $\mathrm{FAp}-\mathrm{TiO}_{2}$ composite nanopowders have cluster-like structure which is composed of ellipse-like nanoparticles with an average size of about $16 \pm 7 \mathrm{~nm}$ after $15 \mathrm{~h}$ of milling. Furthermore, it can be seen that the mean size of intra-agglomerate pores is much smaller than that of the inter-agglomerate pores. Since nanostructured 
bioceramics with ellipse- or rod-like morphology inhibit the proliferation of malignant melanoma cells and may be helpful to remedy cancer [25], the synthesized composite can be considered in biomedical applications. Recalling from the above consequences, the proposed milling media is a proper condition to synthesize bionanocomposites. This result is in good agreement with previous studies that have shown polymeric vial along with zirconia balls is an appropriate milling media to annihilate contamination problems and to achieve modified morphologies with high biomedical performance $[17,25,28]$.

\section{2 Phase analysis}

Figure 3 shows the XRD profile and schematic view of $\mathrm{CaHPO}_{4}, \mathrm{Ca}(\mathrm{OH})_{2}$ and $\mathrm{CaF}_{2}$ powder mixture in the presence of $20 \mathrm{wt} \% \mathrm{TiO}_{2}$ after the beginning of milling.
It is obvious that no trace of $\mathrm{FAp}-\mathrm{TiO}_{2}$ composite is found at the beginning of milling due to the lack of reaction time for mechanical activation. In this case, the phase compositions are $\mathrm{CaHPO}_{4}, \mathrm{Ca}(\mathrm{OH})_{2}, \mathrm{CaF}_{2}$ and $\mathrm{TiO}_{2}$ as shown in Fig. 3(b).

The XRD patterns of the powder mixture after mechanical activation and thermal treatment are shown in Fig. 4. From Fig. 4(a), all the sharp characteristic peaks corresponding to $\mathrm{Ca}(\mathrm{OH})_{2}$ and $\mathrm{CaF}_{2}$ disappear completely after $5 \mathrm{~h}$ of milling. Also several characteristic peaks corresponding to $\mathrm{CaHPO}_{4}$ vanish and a number of new broadened peaks belonging to FAp emerge especially between $2 \theta=31^{\circ}-34^{\circ}$. Accordingly, after $5 \mathrm{~h}$ of milling the main phase compositions are FAp and $\mathrm{TiO}_{2}$. Besides, two minor peaks are found in the XRD patterns which belong to $\mathrm{CaHPO}_{4}$. This shows that non-reacted $\mathrm{CaHPO}_{4}$ is still
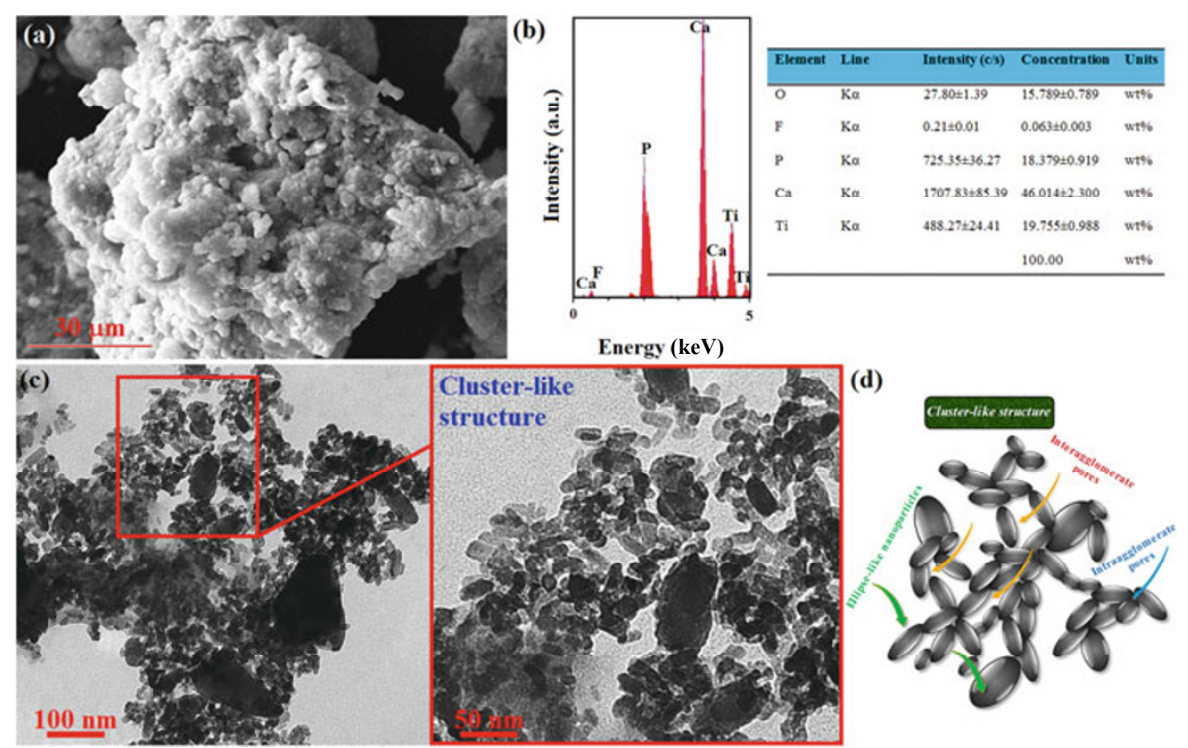

Fig. 2 (a) SEM micrograph, (b) EDX result, (c) TEM images and (d) schematic view of FAp-TiO 2 composite nanopowders.
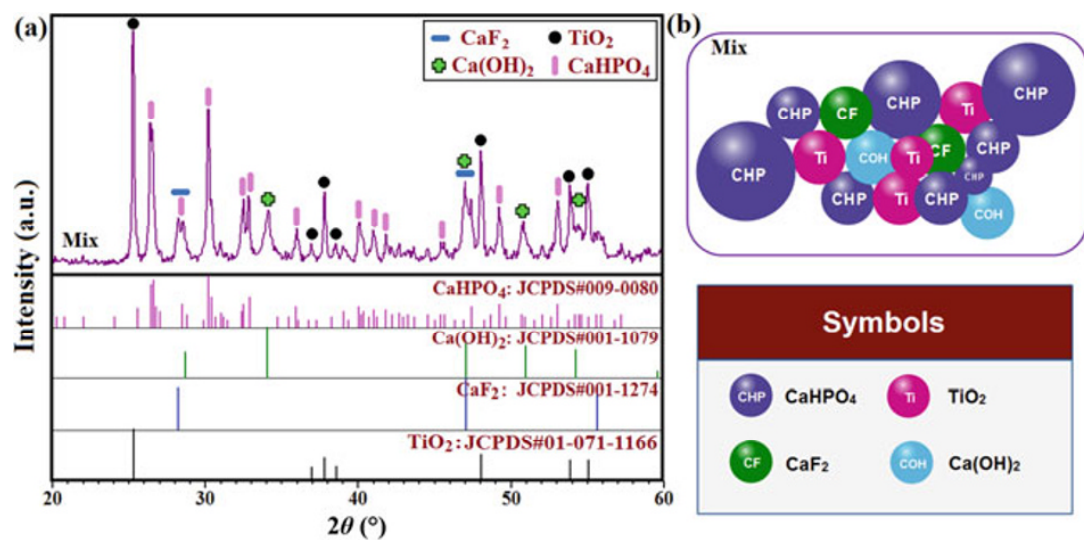

Fig. 3 (a) XRD profile and (b) schematic view of $\mathrm{CaHPO}_{4}, \mathrm{Ca}(\mathrm{OH})_{2}$ and $\mathrm{CaF}_{2}$ powder mixture in the presence of $20 \mathrm{wt} \% \mathrm{TiO}_{2}$ after the beginning of milling. 


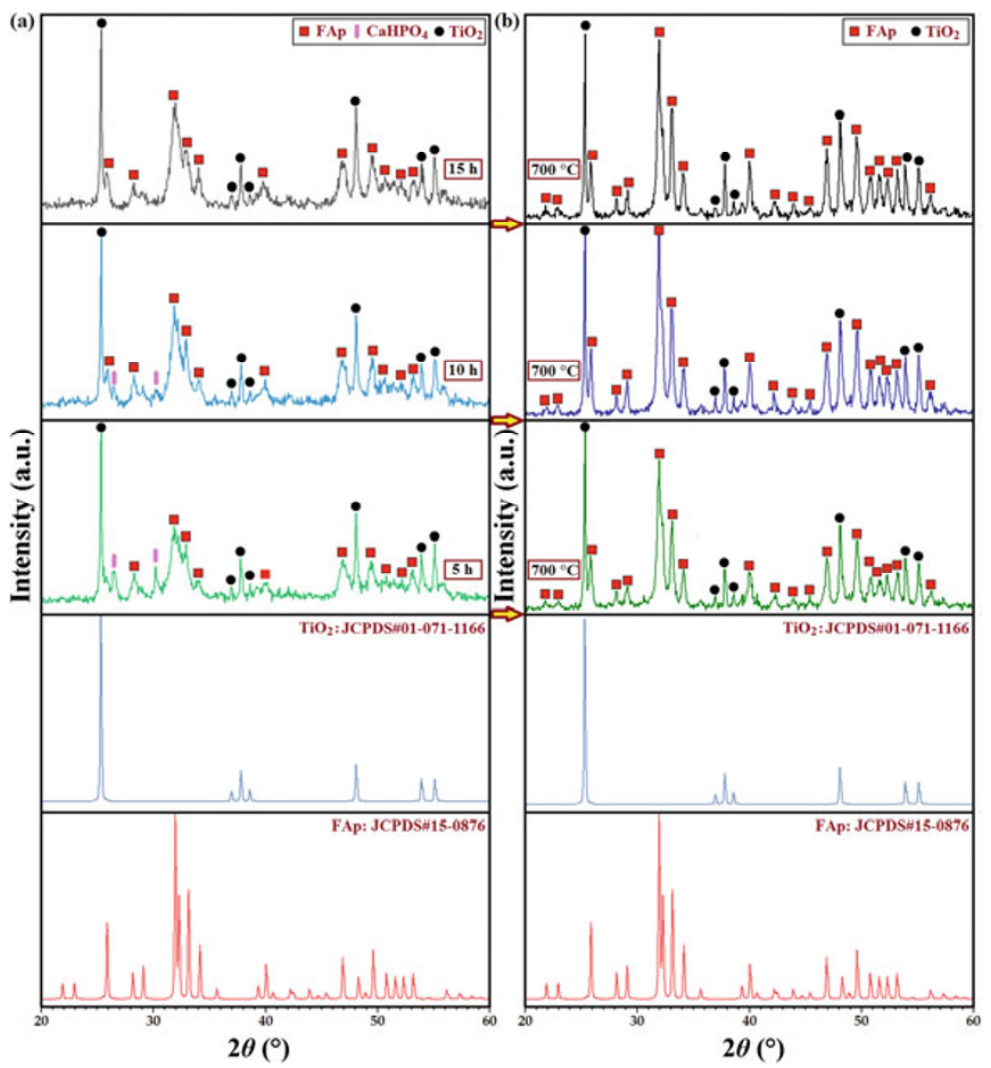

Fig. 4 XRD patterns of the powder mixture (a) after mechanical activation and (b) thermal treatment at $700{ }^{\circ} \mathrm{C}$ for $2 \mathrm{~h}$.

present in the specimen. Further increase in the milling time to $10 \mathrm{~h}$ leads to an increase in the fraction of crystalline phase, as evidenced by the extra sharpening of the characteristic diffraction peaks. In this case, similar to the previous sample, the main product of mechanical activation is $\mathrm{FAp}-\mathrm{TiO}_{2}$ composite. Moreover, two extra peaks corresponding to $\mathrm{CaHPO}_{4}$ show high level of peak broadening due to a decrease in crystallite size and an increase in internal strain. These peaks indicate that the mechanochemical reaction is not yet completed. When the mechanical activation time increases to $15 \mathrm{~h}$, all the peaks corresponding to $\mathrm{CaHPO}_{4}$ disappear entirely and only those belonging to $\mathrm{FAp}$ and $\mathrm{TiO}_{2}$ become evident. In fact, $\mathrm{FAp}-\mathrm{TiO}_{2}$ composite with high phase purity is produced after $15 \mathrm{~h}$ of milling. Figure 4(b) shows the XRD profiles of the mechanically activated samples after thermal treatment at $700{ }^{\circ} \mathrm{C}$ for $2 \mathrm{~h}$. Based on this figure, a noticeable increase in the peak intensity of FAp and $\mathrm{TiO}_{2}$ is observed. It has been found that apatite may be decomposed under thermal treatment in the range of $600-800{ }^{\circ} \mathrm{C}$ [29]. However, it is clear from XRD patterns that the synthesized composite nanopowders are quite stable under annealing at $700{ }^{\circ} \mathrm{C}$. Actually, after heat treatment, high crystalline composite nanopowders are formed and no phase transformation or decomposition occurs. In addition, the breadth of the fundamental diffraction peaks decreases in comparison with the milled powders which can be attributed to a sharp rise in crystallite size and a dramatic decline in lattice strain. From a comparative perspective, the characteristic peaks corresponding to the $10-\mathrm{h}$ and $15-\mathrm{h}$ milled specimens are more intense than those of the 5-h milled sample. This shows that the fraction of crystalline phase in these nanopowders is more than that in the 5-h milled specimen.

\section{3 Effect of strain on XRD patterns}

Figure 5 displays the effect of strain on the direction of XRD patterns of the milled samples before and after annealing at $700{ }^{\circ} \mathrm{C}$. According to Fig. 5(a), the direction of X-ray reflection is influenced by both uniform and non-uniform strains. In the absence of strain, the set of transverse reflecting planes shows a uniform equilibrium spacing $d_{0}$. The diffraction line 
(a)

Crystal lattice
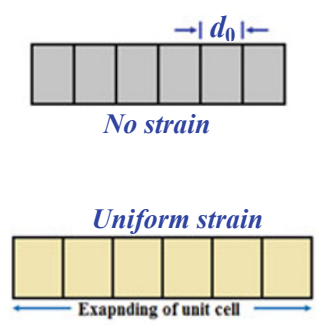

Nonuniform strain

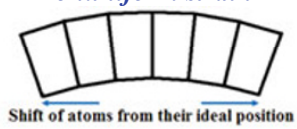

Diffraction line
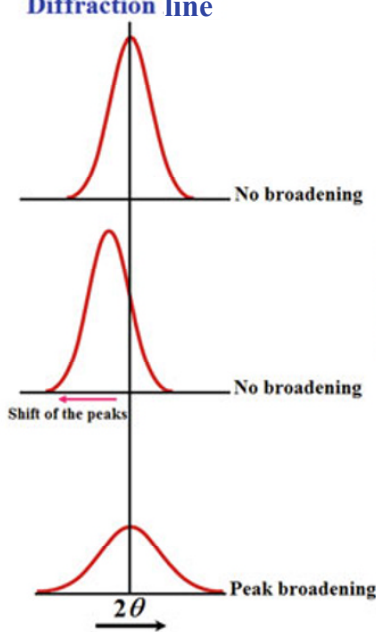

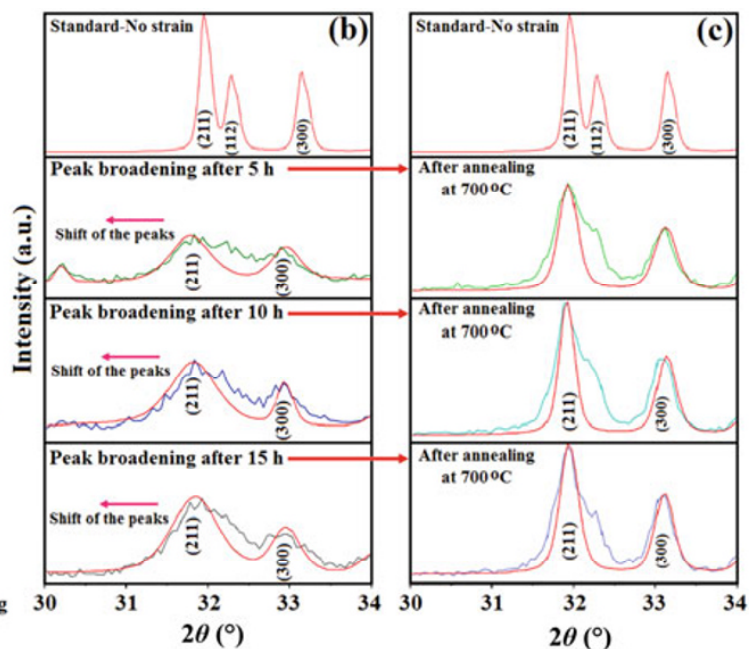

Fig. 5 (a) The effect of strain on the direction of XRD patterns of the milled samples (b) before and (c) after annealing at $700{ }^{\circ} \mathrm{C}$.

out of these planes emerges on the right. No peak broadening is observed in these circumstances. On the other side, in the presence of a uniform tensile strain at right angles, the spacing of reflecting planes becomes larger than $d_{0}$ and the diffraction line shifts to the lower angles. Obviously, similar to the previous model, no peak broadening is observed in this attitude. In the third model, the non-uniform strain leads to the bending of grain. It is obvious that, on the top side (tension), the plane spacing exceeds $d_{0}$, whereas on the bottom side (compression), it is less than $d_{0}$, and somewhere in between, it equals $d_{0}$ [30]. In accordance with Fig. 5(b), the mechanical activation in the range of $5 \mathrm{~h}$ to $15 \mathrm{~h}$ is accompanied by the simultaneous presence of uniform (macro-) and non-uniform (micro-) strains which result in peak shift and peak broadening, respectively. After thermal treatment at $700{ }^{\circ} \mathrm{C}$ (Fig. $5(\mathrm{c})$ ), recovery of crystal lattice occurs, and as a result, the characteristic peaks intensify and shift to the standard position. Based on the theory of kinematical scattering, XRD peaks broaden either when crystallite becomes smaller than about a micrometer or if lattice defects are present in large enough abundance [31]. Hence, the structural features of the mechanosynthesized nanopowders should be determined by XRD profiles.

\section{4 Crystallite size and lattice strain}

Several theoretical models have been developed to obtain structural information through mathematical analysis of the XRD profile [22,31]. Among them, the Williamson-Hall equation is a simplified integral breadth method which is based on the broadening of the diffraction lines due to the strain and crystallite size. This equation is expressed as follows:

$$
B \cos \theta=\frac{0.9 \lambda}{D}+\eta \sin \theta
$$

where $\lambda, D, \eta$ and $\theta$ are the wavelength of the X-ray used $(0.154056 \mathrm{~nm})$, the crystallite size, the internal micro-strain and the Bragg angle, respectively. Note that $B$ in the above equation is the peak width (in radians) after subtracting the peak width due to instrumental broadening from the experimentally recorded profile. Therefore, when $B \cos \theta$ is plotted against $\sin \theta$, straight lines are obtained for samples with the slope as $\eta$ and the intercept as $0.9 \lambda / D$.

Figure 6 shows the crystallite size and lattice strain of the milled samples before and after thermal treatment at $700{ }^{\circ} \mathrm{C}$ for $2 \mathrm{~h}$. It is evident that with increasing the milling time from $5 \mathrm{~h}$ to $15 \mathrm{~h}$, the crystallite size of the samples fluctuates slightly and reaches a minimum around $21.66 \mathrm{~nm}$ after $15 \mathrm{~h}$ of milling (Fig. 6(a)). Similarly, the lattice strain varies slightly during the milling process and reaches a maximum about -0.007 after $15 \mathrm{~h}$ of milling (Fig. 6(b)). It should be noted that the negative coefficient is because of compressive stress caused by the impacts. After thermal treatment of the samples, the crystallite size increases significantly to around $277.3 \mathrm{~nm}$, $462.17 \mathrm{~nm}$ and $231.08 \mathrm{~nm}$ for the $5-\mathrm{h}, 10-\mathrm{h}$ and $15-\mathrm{h}$ milled samples, respectively. On the contrary, the lattice strain declines dramatically to around 0.0008 , 0.0011 and 0.0007 for the 5-h, 10-h and 15-h milled 


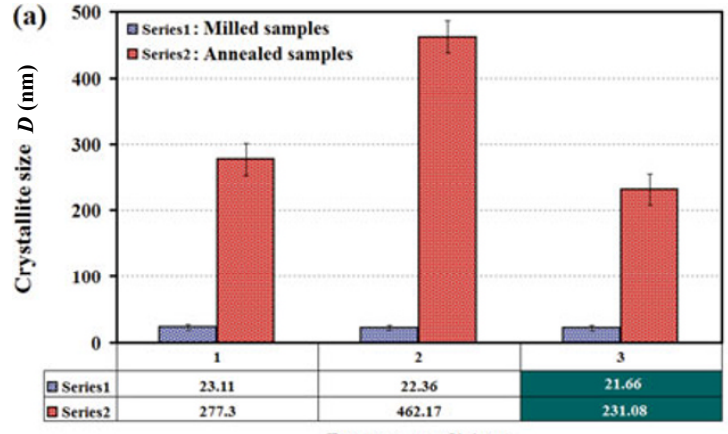

Process conditions

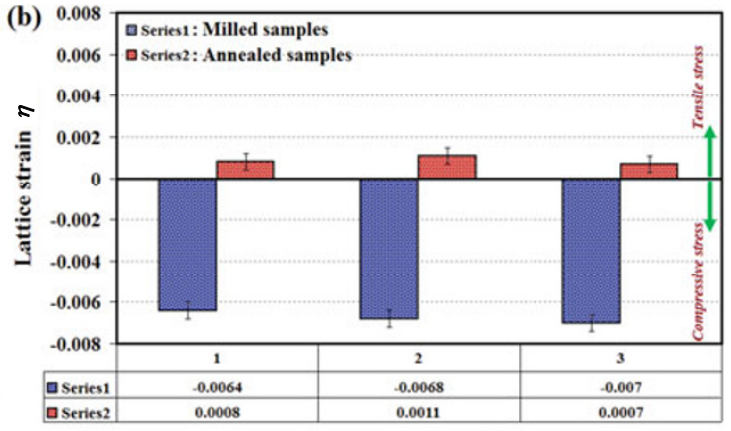

Process conditions

Fig. 6 (a) The crystallite size and (b) lattice strain of the milled samples before and after thermal treatment at $700{ }^{\circ} \mathrm{C}$ for $2 \mathrm{~h}$.

samples, respectively. Furthermore, it is obvious that the compressive stress is changed to low tensile stress during annealing at $700{ }^{\circ} \mathrm{C}$. According to these results, it can be concluded that the crystallite size and lattice strain of the milled samples are strongly influenced by the thermal treatment.

\section{5 Volume fraction of grain boundary}

If we assume that a crystallite is a sphere of diameter $D$ surrounded by a shell of grain boundary with thickness $t$, the volume fraction of grain boundary $f$ is approximately [32]:

$$
f=1-\left(\frac{D}{D+t}\right)^{3}
$$

Here, the values of $f$ are calculated by substituting the determined values of crystallite size obtained from the Williamson-Hall plots with $D$ under the assumption of $t=1 \mathrm{~nm}$.

Figure 7 shows the volume fraction of grain boundary of the milled specimens before and after annealing at $700{ }^{\circ} \mathrm{C}$ for $2 \mathrm{~h}$. From this figure, it is evident that the percentage of volume fraction of grain boundary goes up a little with increasing the milling time and reaches around $12.66 \%$ after $15 \mathrm{~h}$ of milling. In a similar trend, the percentage of volume fraction of grain boundary reaches a maximum around $1.29 \%$ after annealing of the 15 -h milled sample at $700{ }^{\circ} \mathrm{C}$. From a comparative view, these significant variations in percentage of volume fraction of grain boundary result mainly from the difference in crystallite size of the samples before and after annealing. These results suggest that by choosing appropriate milling and annealing conditions, bioceramics with various nanostructural features may be generated that can be used depending on the application.

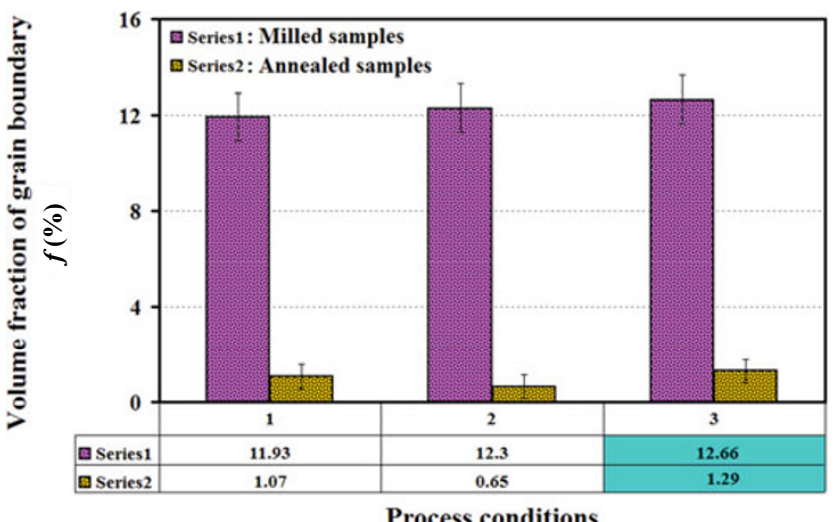

Fig. 7 The volume fraction of grain boundary of the milled specimens before and after annealing at $700{ }^{\circ} \mathrm{C}$ for $2 \mathrm{~h}$.

\section{6 Crystallinity degree}

The crystallinity degree $\left(X_{\mathrm{c}}\right)$, corresponding to the fraction of crystalline phase present in the examined volume, is estimated for all the milled specimens before and after thermal treatment at $700{ }^{\circ} \mathrm{C}$ by taking the sum total of relative intensities of individual characteristic peaks according to the following equation [33]:

$$
X_{\mathrm{c}}=\frac{\operatorname{Sum}\left(I_{1}: I_{n}\right)_{\mathrm{FAp}}}{\operatorname{Sum}\left(I_{1}: I_{n}\right)_{\text {Standard }}} \times 100 \%
$$

where $I_{1}: I_{n}$ is the total of relative intensities of characteristic peaks of FAp for both the synthesized powders and standard. Figure 8 displays the crystallinity degree of the milled samples before and after thermal treatment at $700{ }^{\circ} \mathrm{C}$. According to the obtained data, the sum total of relative intensities of FAp peaks are $153.06 \%, 198.87 \%$ and $212.30 \%$ after $5 \mathrm{~h}, 10 \mathrm{~h}$ and $15 \mathrm{~h}$ of milling, respectively. This value for the standard is $554 \%$. As a result, based on the 


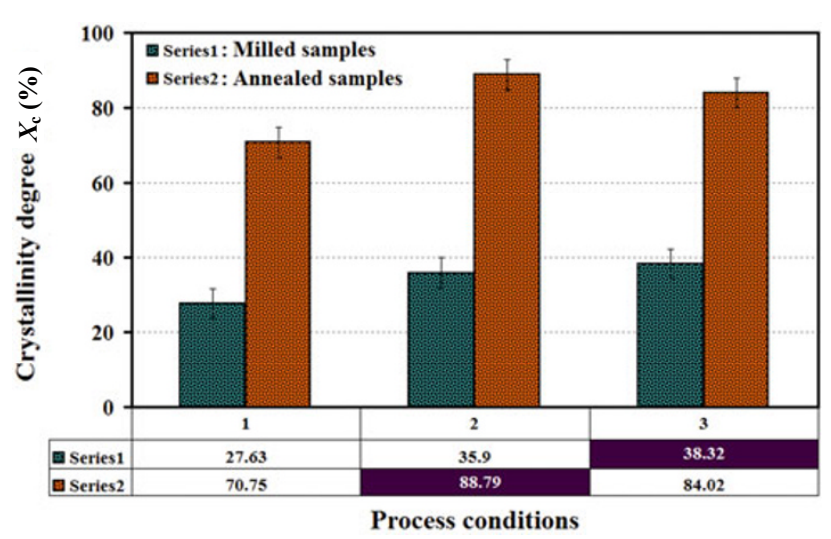

Fig. 8 The crystallinity degree of the milled samples before and after thermal treatment at $700{ }^{\circ} \mathrm{C}$.

equation's output, the crystallinity degree increases from $27.63 \%$ to $38.32 \%$ when the mechanical activation time goes up from $5 \mathrm{~h}$ to $15 \mathrm{~h}$. These results are in good agreement with XRD profiles which show an extra sharpening of the characteristic peaks with further increasing the mechanical activation time to $15 \mathrm{~h}$. The milled samples can be utilized to promote osseointegration or as a coating to promote bone ingrowth into prosthetic implants owing to their low level of crystallinity [34]. After thermal treatment at $700{ }^{\circ} \mathrm{C}$, the sum total of relative intensities of FAp peaks reach around $391.94 \%, 491.94 \%$ and $465.46 \%$ for the 5-h, 10-h and 15-h milled samples, respectively. This shows that the crystallinity degree reaches a maximum around $88.79 \%$ after heating of the $10-\mathrm{h}$ milled sample and after that goes down gradually to $84.02 \%$ after annealing of the 15 -h milled specimen. Since apatite with high crystallinity degree shows little or no activity towards bioresorption and are insoluble in physiological environment [35], the annealed samples with high crystallinity degree are well preferred for dental applications. In a nutshell, the obtained data indicate that, similar to the other structural features (i.e., crystallite size, micro-strain and the volume fraction of grain boundary), the crystallinity degree of mechano-synthesized bioceramics is effectively influenced by the milling time and subsequent annealing.

\section{7 Lattice parameters}

The relation between lattice spacing $(d)$ and lattice parameters $(a, b$ and $c)$ of FAp in the composite structures before and after thermal treatment is shown as

$$
\frac{1}{d^{2}}=\frac{4}{3} \frac{h^{2}+h k+k^{2}}{a^{2}}+\frac{l^{2}}{c^{2}}
$$

where $h, k$ and $l$ are the Miller indices of the reflection planes. The (002) and (300) reflections are chosen for the lattice parameter calculation [36].

Moreover, volume of fluorapatite HCP unit cell $(V)$ is determined using the following equation [37]:

$$
V=3 a^{2} c \sin 60^{\circ}
$$

Figure 9 shows the unit cell measurements ( $a$-axis, $c$-axis and unit cell volume $(V))$ of FAp as a function of
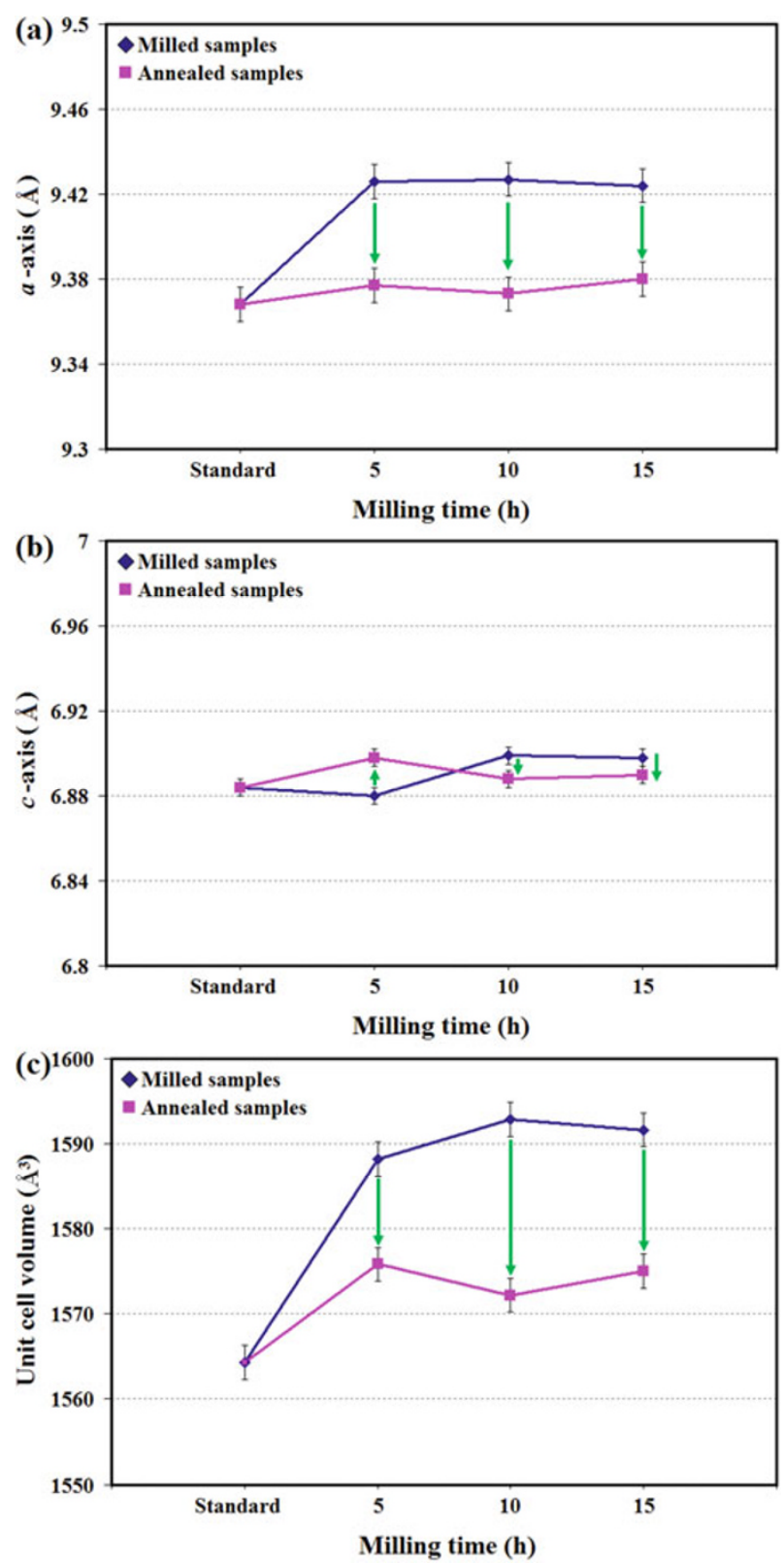

Fig. 9 Unit cell measurements: (a) $a$-axis, (b) $c$-axis and (c) unit cell volume of FAp as a function of milling time and subsequent annealing. 
milling time and subsequent annealing. As shown in Fig. 9(a), the $a$-axis values for all the milled samples are higher than the reported value for standard (JCPDS\#15-0876: $a=9.368 \AA$ ). It can be seen that the $a$-axis value of FAp increases notably first to $9.426 \AA$ for the 5-h milled specimen and then with increasing the milling time to $15 \mathrm{~h}$ goes down slightly to $9.424 \AA$.

After thermal treatment at $700{ }^{\circ} \mathrm{C}$, recovery of the crystal lattice occurs and as a consequence the $a$-axis quantities reach approximately the standard value as shown in Fig. 9(a). This behavior is particularly evident for the 10-h milled sample after thermal treatment. From Fig. 9(b), the $c$-axis values for all the milled samples before and after annealing are similar to the reported value for standard (JCPDS\#15-0876: $c=6.884 \AA$ ). Therefore, the variations in unit cell volume result mainly from a rise in the " $a$ " parameter, rather than from the " $c$ " values and can probably be related to the lattice distortion of FAp during solid-state process (Fig. 9(c)). However, the 5-h milled sample before annealing and the 10-h milled specimen after annealing at $700{ }^{\circ} \mathrm{C}$ are closer to the standard values among all the samples. It should be noted that the modest increase in the amount of $c$-axis value for the 5-h milled sample after annealing can be related to the transferred thermal stress to particles during annealing at $700{ }^{\circ} \mathrm{C}$. In short, the results reveal that the recovery of the crystal lattice can occur and as a result high-quality and stable nanostructures can be achieved by annealing in proper conditions.

\section{Evaluation of the functional groups}

Figure 10 shows the FT-IR spectra of $\mathrm{FAp}-\mathrm{TiO}_{2}$ composite nanopowders after thermal annealing process at $700{ }^{\circ} \mathrm{C}$ for $2 \mathrm{~h}$. In general, the functional groups of apatite are $\mathrm{PO}_{4}^{3-}, \mathrm{OH}^{-}, \mathrm{CO}_{3}^{2-}$ and $\mathrm{HPO}_{4}^{2-}$ groups which are generally observed in $4000-400 \mathrm{~cm}^{-1}$ region in the FT-IR spectra $[17,27,38-41]$. For the heat-treated samples, these characteristic bands are assigned here:

(a) After annealing of the 5-h milled sample, two bands are observed at $3483.66 \mathrm{~cm}^{-1}$ and $1643.45 \mathrm{~cm}^{-1}$ due to the vibration of the adsorbed water in apatite [38]. The first band $\left(3483.66 \mathrm{~cm}^{-1}\right)$ shifts to $3466.30 \mathrm{~cm}^{-1}$ and $3483.66 \mathrm{~cm}^{-1}$ for the $10-\mathrm{h}$ and $15-\mathrm{h}$ milled samples, respectively.

(b) For the 5-h milled sample, the bands at

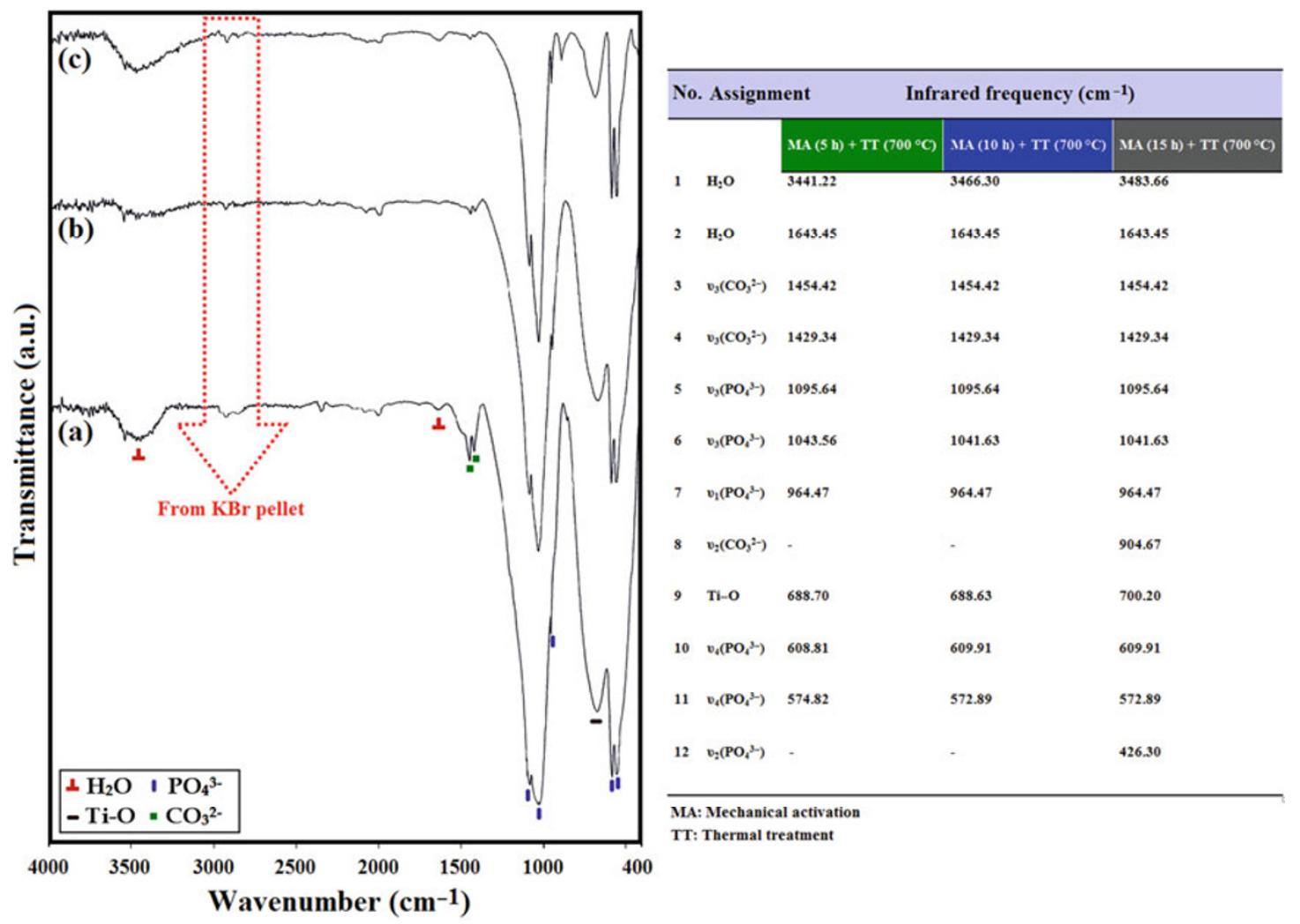

Fig. 10 The FT-IR spectra of the mechano-synthesized composite nanopowders after thermal treatment: (a) MA $(5 \mathrm{~h})+\mathrm{TT}\left(700{ }^{\circ} \mathrm{C}\right) ;(\mathrm{b}) \mathrm{MA}(10 \mathrm{~h})+\mathrm{TT}\left(700{ }^{\circ} \mathrm{C}\right)$; and (c) MA $(15 \mathrm{~h})+\mathrm{TT}\left(700{ }^{\circ} \mathrm{C}\right)$. 
$1095.64 \mathrm{~cm}^{-1}$ and $1043.56 \mathrm{~cm}^{-1}$ ascribe to $v_{3} \mathrm{PO}_{4}$, the band at $964.47 \mathrm{~cm}^{-1}$ comes from $v_{1} \mathrm{PO}_{4}$, and the bands at $609.01 \mathrm{~m}^{-1}$ and $574.82 \mathrm{~cm}^{-1}$ result from $v_{1}$ $\mathrm{PO}_{4}$ [36,38]. These bands shift to $1095.64 \mathrm{~cm}^{-1}$, $1041.63 \mathrm{~cm}^{-1}, 609.91 \mathrm{~cm}^{-1}$ and $572.89 \mathrm{~cm}^{-1}$ for the 10-h and 15-h milled specimens. The band at $964.47 \mathrm{~cm}^{-1}$ remains stable after different milling durations.

(c) After thermal treatment of the 5-h milled specimen, a doublet appears at $1454.42 \mathrm{~cm}^{-1}$ and $1429.34 \mathrm{~cm}^{-1}$ corresponds to $v_{3}$ vibration mode of the carbonated groups. The position of these peaks does not change after $10 \mathrm{~h}$ and $15 \mathrm{~h}$ of milling. It is obvious that the intensity of these bands decreases with increasing milling time to $15 \mathrm{~h}$. Besides, a sharp peak corresponding to $v_{2} \quad \mathrm{CO}_{3}$ appears after thermal treatment of the 15-h milled specimen. The presence of these peaks shows that FAp as the main phase of composite nanopowders contains some $\mathrm{CO}_{3}^{2-}$ groups in $\mathrm{PO}_{4}^{3-}$ sites of apatite lattice (B-type substitution) $[39,40]$. It has been reported that this kind of apatite is more similar to biological apatite and can be very useful for bone replacement materials [13].

(d) The presence of $\mathrm{TiO}_{2}$ is approved by the appearance of Ti-O vibration band at $688.70 \mathrm{~cm}^{-1}$, $688.63 \mathrm{~cm}^{-1}$ and $700.20 \mathrm{~cm}^{-1}$ for the $5-\mathrm{h}, 10-\mathrm{h}$ and 15-h milled samples, respectively [41]. Based on FT-IR spectra, the synthesized composite nanopowders show high chemical purity which is very important in biomedical applications.

Recalling from the above consequences, solid-state process including milling and subsequent annealing influences the mechanochemical behavior of $\mathrm{CaHPO}_{4}-\mathrm{Ca}(\mathrm{OH})_{2}-\mathrm{CaF}_{2}-\mathrm{TiO}_{2}$ system.

\section{Conclusions}

The influence of milling time and subsequent thermal treatment on mechanochemical behavior and structural features of the $\mathrm{CaHPO}_{4}-\mathrm{Ca}(\mathrm{OH})_{2}-\mathrm{CaF}_{2}-\mathrm{TiO}_{2}$ system was investigated. Results showed that fluorapatitetitania composite nanopowders with high phase purity was obtained after $15 \mathrm{~h}$ of milling. After annealing at $700{ }^{\circ} \mathrm{C}$, high crystalline composite nanopowders were formed and no phase transformation or decomposition occurred. The obtained data from Williamson-Hall method was in good agreement with TEM analysis. According to the results, the mechanical activation in the range of $5-15 \mathrm{~h}$ was accompanied by the simultaneous presence of uniform (macro-) and non-uniform (micro-) strains which resulted in both peak shift and peak broadening, respectively. After thermal treatment at $700{ }^{\circ} \mathrm{C}$, recovery of crystal lattice occurred and as a result the characteristic peaks intensified and shifted to the standard position. In addition, the compressive stress was changed to low tensile stress during annealing at $700{ }^{\circ} \mathrm{C}$. The crystallinity degree increased from $27.63 \%$ to $38.32 \%$ when the mechanical activation duration went up from $5 \mathrm{~h}$ to $15 \mathrm{~h}$. After thermal treatment at $700{ }^{\circ} \mathrm{C}$, the crystallinity degree reached a maximum around $88.79 \%$. Altogether, the evaluation of the structural features confirmed that the crystallite size, micro-strain, the volume fraction of grain boundary, crystallinity degree and lattice parameters of mechano-synthesized $\mathrm{FAp}-\mathrm{TiO}_{2}$ composite were effectively influenced by the subsequent annealing.

\section{Acknowledgements}

The authors are grateful to research affairs of Islamic Azad University, Najafabad Branch for supporting of this research.

Open Access: This article is distributed under the terms of the Creative Commons Attribution License which permits any use, distribution, and reproduction in any medium, provided the original author(s) and the source are credited.

\section{References}

[1] Suryanarayana C, Al-Aqeeli N. Mechanically alloyed nanocomposites. Prog Mater Sci 2013, 58: 383-502.

[2] Okada M, Furuzono T. Hydroxylapatite nanoparticles: Fabrication methods and medical applications. Sci Technol Adv Mater 2012, 13: 064103.

[3] Zhou H, Lee J. Nanoscale hydroxyapatite particles for bone tissue engineering. Acta Biomater 2011, 7: 2769-2781.

[4] Ye F, Guo H, Zhang H, et al. Polymeric micelle-templated synthesis of hydroxyapatite hollow nanoparticles for a drug delivery system. Acta Biomater 2010, 6: 2212-2218.

[5] Ono I, Yamashita T, Jin HY, et al. Combination of porous hydroxyapatite and cationic liposomes as a vector for BMP-2 gene therapy. Biomaterials 2004, 25: 4709-4718. 
[6] Shepard SR, Brickman-Stone C, Schrimsher JL, et al. Discoloration of ceramic hydroxyapatite used for protein chromatography. J Chromatogr A 2000, 891: 93-98.

[7] Molle P, Liénard A, Grasmik A. Apatite as an interesting seed to remove phosphorus from wastewater in constructed wetlands. Water Sci Technol 2005, 51: 193-203.

[8] Suresh Kumar G, Girija EK. Flower-like hydroxyapatite nanostructure obtained from eggshell: A candidate for biomedical applications. Ceram Int 2013, 39: 8293-8299.

[9] Liu H, Webster TJ. Nanomedicine for implants: A review of studies and necessary experimental tools. Biomaterials 2007, 28: 354-369.

[10] Niespodziana K, Jurczyk K, Jakubowicz J, et al. Fabrication and properties of titaniumhydroxyapatite nanocomposites. Mater Chem Phys 2010, 123: 160-165.

[11] Fini M, Savarino L, Nicoli Aldini N, et al. Biomechanical and histomorphometric investigations on two morphologically differing titanium surfaces with and without fluorohydroxyapatite coating: An experimental study in sheep tibiae. Biomaterials 2003, 24: 3183-3192.

[12] Chen Y, Miao X. Thermal and chemical stability of fluorohydroxyapatite ceramics with different fluorine contents. Biomaterials 2005, 26: 1205-1210.

[13] Fathi MH, Mohammadi Zahrani E. Mechanical alloying synthesis and bioactivity evaluation of nanocrystalline fluoridated hydroxyapatite. J Cryst Growth 2009, 311: 1392-1403.

[14] Sadat-Shojai M, Khorasani M-T, DinpanahKhoshdargi E, et al. Synthesis methods for nanosized hydroxyapatite with diverse structures. Acta Biomater 2013, 9: 7591-7621.

[15] Arcos D, Vallet-Regí M. Bioceramics for drug delivery. Acta Mater 2013, 61: 890-911.

[16] Dorozhkin SV. Bioceramics of calcium orthophosphates. Biomaterials 2010, 31: 1465-1485.

[17] Ebrahimi-Kahrizsangi R, Nasiri-Tabrizi B, Chami A. Synthesis and characterization of fluorapatite-titania $\left(\mathrm{FAp}-\mathrm{TiO}_{2}\right)$ nanocomposite via mechanochemical process. Solid State Sci 2010, 12: 1645-1651.

[18] Ramachandra Rao R, Kannan TS. Synthesis and sintering of hydroxyapatite-zirconia composites. Mat Sci Eng C 2002, 20: 187-193.

[19] Viswanath B, Ravishankar N. Interfacial reactions in hydroxyapatite/alumina nanocomposites. Scripta Mater 2006, 55: 863-866.

[20] Choi J-W, Kong Y-M, Kim H-E, et al. Reinforcement of hydroxyapatite bioceramic by addition of $\mathrm{Ni}_{3} \mathrm{Al}$ and $\mathrm{Al}_{2} \mathrm{O}_{3} . J$ Am Ceram Soc 1998, 81: 1743-1748.

[21] Ortiz AL, Shaw L. X-ray diffraction analysis of a severely plastically deformed aluminum alloy. Acta Mater 2004, 52: 2185-2197.

[22] Suryanarayana C. Mechanical alloying and milling. Prog Mater Sci 2001, 46: 1-184.

[23] Tao NR, Wang ZB, Tong WP, et al. An investigation of surface nanocrystallization mechanism in $\mathrm{Fe}$ induced by surface mechanical attrition treatment. Acta Mater 2002, 50: 4603-4616.

[24] Venkateswarlu K, Chandra Bose A, Rameshbabu N. $\mathrm{X}$-ray peak broadening studies of nanocrystalline hydroxyapatite by Williamson-Hall analysis. Physica B 2010, 405: 4256-4261.

[25] Honarmandi P, Honarmandi P, Shokuhfar A, et al. Milling media effects on synthesis, morphology and structural characteristics of single crystal hydroxyapatite nanoparticles. Adv Appl Ceram 2010, 109: 117-122.

[26] Klug HP, Alexander LE. X-ray Diffraction Procedures: For Polycrystalline and Amorphous Materials. New York: Wiley, 1974.

[27] Nasiri-Tabrizi B, Fahami A. Crystallinity evaluation of cluster-like fluorapatite-titania nanocomposites. J Clust Sci 2013, DOI: 10.1007/s10876-013-0623-y.

[28] Ebrahimi-Kahrizsangi R, Nasiri-Tabrizi B, Chami A. Characterization of single-crystal fluorapatite nanoparticles synthesized via mechanochemical method. Particuology 2011, 9: 537-544.

[29] Fathi MH, Hanifi A. Evaluation and characterization of nanostructure hydroxyapatite powder prepared by simple sol-gel method. Mater Lett 2007, 61: 3978-3983.

[30] Khorsand Zak A, Majid WHA, Abrishami ME, et al. $\mathrm{X}$-ray analysis of $\mathrm{ZnO}$ nanoparticles by Williamson-Hall and size-strain plot methods. Solid State Sci 2011, 13: 251-256.

[31] Balaz P. Mechanochemistry in Nanoscience and Minerals Engineering. Berlin Heidelberg: Springer, 2008.

[32] Sun F, Froes FHS. Synthesis and characterization of mechanical-alloyed $\mathrm{Ti}-x \mathrm{Mg}$ alloys. J Alloys Compd 2002, 340: 220-225.

[33] Rayalu SS, Udhoji JS, Meshram SU, et al. Estimation of crystallinity in flyash-based zeolite-A using XRD and IR spectroscopy. Curr Sci 2005, 89: 2147-2151.

[34] Sanosh KP, Chu MC, Balakrishnan A, et al. Synthesis of nano hydroxyapatite powder that simulate teeth particle morphology and composition. Curr Appl Phys 2009, 9: 1459-1462.

[35] Seckler MM, Danese M, Derenzo S, et al. Influence 
of process conditions on hydroxyapatite crystallinity obtained by direct crystallization. Mat Res 1999, 2 : 59-62.

[36] Nasiri-Tabrizi B, Fahami A. Effect of zirconia content on the mechanosynthesis and structural features of fluorapatite-based composite nanopowders. Ceram Int 2013, 39: 7331-7342.

[37] Smith WF, Hashemi J. Foundations of Materials Science and Engineering. NewYork: McGraw-Hill Science, 2004: 67-115.

[38] Nath S, Tripathi R, Basu B. Understanding phase stability, microstructure development and biocompatibility in calcium phosphate-titania composites, synthesized from hydroxyapatite and titanium powder mixture. Mat Sci Eng C 2009, 29:
97-107.

[39] Lafon JP, Champion E, Bernache-Assollant D. Processing of AB-type carbonated hydroxyapatite $\mathrm{Ca}_{10-x}\left(\mathrm{PO}_{4}\right)_{6-x}\left(\mathrm{CO}_{3}\right)_{x}(\mathrm{OH})_{2-x-2 y}\left(\mathrm{CO}_{3}\right)_{y}$ ceramics with controlled composition. J Eur Ceram Soc 2008, 28: 139-147.

[40] Kheradmandfard M, Fathi MH. Fabrication and characterization of nanocrystalline $\mathrm{Mg}$-substituted fluorapatite by high energy ball milling. Ceram Int 2013, 39: 1651-1658.

[41] Pushpakanth S, Srinivasan B, Sreedhar B, et al. An in situ approach to prepare nanorods of titania-hydroxyapatite $\left(\mathrm{TiO}_{2}-\mathrm{HAp}\right)$ nanocomposite by microwave hydrothermal technique. Mater Chem Phys 2008, 107: 492-498. 